\title{
KAJIAN KERAPATAN DAN KERAGAMAN ORGANISME TANAH GAMBUT DI BAWAH TEGAKAN TANAMAN KELAPA SAWIT MENGHASILKAN
}

\section{STUDY OF DENSITY AND DIVERSITY OF SOIL ORGANISMS UNDER MATURE OIL PALM ON PEATLAND}

\author{
Fandi Hidayat, Rana Farrasati, dan Winarna
}

\begin{abstract}
Abstrak Penelitian ini dilaksanakan di lahan gambut pada Kebun Panai Jaya, PT Perkebunan Nusantara IV, Provinsi Sumatera Utara. Metode pengambilan sampel yang digunakan dengan cara Pit Fall Trap (untuk menjebak fauna permukaan tanah), Barlese Tullgren (untuk melihat fauna tanah yang aktif di dalam tanah) dan membuat lubang (untuk mendapatkan cacing). Metode yang mendapatkan fauna terbanyak yaitu dengan cara Pit Fall Trap. Fauna tanah berkorelasi positif terhadap suhu, kadar air dan respirasi tanah, sedangkan terhadap $\mathrm{pH}$ dan $\mathrm{C} / \mathrm{N}$ berkorelasi negatif. Hasil penelitian menunjukkan, diantara fauna tanah pada plot penelitian, diketahui bahwa jumlah fauna yang paling mendominasi adalah semut rangrang dan diikuti oleh cacing tanah. Baik fauna tanah (makrofauna dan mesofauna) dan mikroorganisme eukariotik tanah (jamur dan bakteri) ditemukan paling banyak pada areal rumpukan kebun kelapa sawit.
\end{abstract}

Kata kunci: Fauna Tanah, Mikroorganisme Tanah, Gambut, dan Kelapa Sawit.

Abstract This study was conducted on peat land in Kebun Panai Jaya, PT Perkebunan Nusantara IV, North Sumatera province. The sampling method was Pit Fall Trap to trap ground level fauna, Barlese Tullgren to observe the active soil fauna in the soil, and making a soil hole to get the worms sample. The Pit Fall Trap could collect the highest number of the fauna. The soil fauna was positively correlated to temperature, soil moisture, and soil respiration, and it was negatively

Penulis yang tidak disertai dengan catatan kaki instansi adalah penelit pada Pusat Penelitian Kelapa Sawit

Fandi Hidayat ( $\square)$

Pusat Penelitian Kelapa Sawit

Jl. Brigjen Katamso No. 51 Medan 20158

Email: fandi.hidayat87@gmail.com correlated to soil $\mathrm{pH}$ and $\mathrm{C} / \mathrm{N}$ ratio. This study showed that, among the soil fauna that found on the observed field, the dominated organisms are weaver ants and followed with earthworms. Both soil fauna (macro and mesofauna) and eukaryotic soil microorganism (fungi and bacteria) were highly found under the frond piles of oil palm plantation.

Keywords: Soil fauna, Soil microorganism, Soil biology, Peatland, and Oil Palm

\section{PENDAHULUAN}

Penggunaan lahan gambut untuk perkebunan kelapa sawit dihadapkan pada permasalahan isu lingkungan yang ditimbulkannya seperti emisi gas rumah kaca (GRK), penurunan keragaman hayati, kekeringan dan kerusakan tanah gambut. Banyak upaya yang telah dilakukan dalam rangka untuk menjaga kelestarian tanah gambut sejalan dengan peningkatan produktivitas kelapa sawit, seperti tata air, aplikasi amelioran, dan pengembangan tanaman penutup tanah (Arifin et al., 2015; Winarna et al., 2016; Winarna et al., 2017 ). Tolak ukur keberhasilan pengelolaan lahan gambut terhadap kelestarian tanah gambut dilihat dari minimnya permasalahan lingkungan yang ditimbulkan. Pada aspek keragaman hayati dalam tanah, keberadaan dan peran fauna tanah dapat menjadi indikator yang cukup baik kaitannya dengan perbaikan kualitas biologi tanah gambut (Maftu'ah et al., 2005; Briones, 2014; Nusantara and Aspan, 2017).

Organisme tanah memiliki peranan yang sangat penting dalam perombakan zat atau bahan-bahan organik dengan cara menghancurkan jaringan secara fisik dan meningkatkan ketersediaan daerah bagi aktifitas bakteri dan jamur, melakukan perombakan pada bahan pilihan seperti gula, selulosa dan sejenis 
lignin, merubah sisa-sisa tumbuhan menjadi humus, menggabungkan bahan yang membusuk pada lapisan tanah bagian atas dan membentuk bahan organik dan bahan mineral tanah, serta membentuk agregat tanah melalui interaksi antara bahan organik dan bahan mineral tanah (Barnes et al., 1997; Bhadauria and Saxena, 2010).

Kualitas tanah gambut sangat dipengaruhi oleh keberadaan dan peran organisme tanah baik mikroorganisme, meso fauna, maupun makro fauna tanah (Maftu'ah et al., 2005; Briones, 2014). Semakin banyak jumlah organisme tanah, menunjukkan terdapatnya indikasi bahwa kondisi tanah gambut akan semakin subur. Oleh karena itu, penelitian ini bertujuan untuk mengkaji keragaman organisme tanah gambut di perkebunan kelapa sawit, baik makro, meso maupun mikro fauna tanah sebagai indikator kualitas biologi tanah gambut yang diamati.

\section{BAHAN DAN METODE}

\section{Lokasi Penelitian}

Penelitian dilaksanakan di perkebunan kelapa sawit yang secara administrasi berada di wilayah Kecamatan Panai Tengah, Kabupaten Labuhan Batu, Propinsi Sumatera Utara. Blok tanaman kelapa sawit yang digunakan sebagai petak penelitian adalah tanaman berumur 6 tahun pada posisi geografi $2^{\circ} 22^{\prime} 25^{\prime \prime}-2^{\circ} 22^{\prime} 50^{\prime \prime} \mathrm{N}$ dan $100^{\circ} 16^{\prime} 0^{\prime \prime}$ - $100^{\circ} 17^{\prime} 10^{\prime \prime} \mathrm{E}$. Perkebunan kelapa sawit ini berada pada lahan gambut dengan ketebalan berkisar 343,65 - 502,92 $\mathrm{cm}$, dengan tingkat kematangan berkisar hemik saprik. Sampel diambil pada tahun 2014 dengan tanamana kelapa sawit tahun tanam 2008 (berumur 6 tahun). Penelitian juga dilakukan di Laboratorium Biologi Tanah Pusat Penelitian Kelapa Sawit, sedangkan identifikasi fauna tanah atau organisme tanah dilakukan di Laboratorium Mikrobiologi Tanah Universitas Sumatera Utara.

\section{Bahan dan Alat}

Bahan-bahan yang digunakan dalam percobaan ini meliputi tanah gambut yang diambil dari lokasi perkebunan kelapa sawit, deterjen, $\mathrm{KOH}, \mathrm{HCl}$ alkohol $25 \%$ dan $80 \%$. Alat-alat yang digunakan adalah mikroskop stereo, Barlese Tullgren, kaca pembesar, penggaris, terpal, cangkul, pinset, pisau, tojok, jarum, tisu, beaker glass, autoclave, $\mathrm{pH}$ meter, pipet tetes, petridish, kamera, bor tanah, ajir, parang, tali rafia, termometer, kantong plastik, stoples, dan alat-alat laboratorium lainnya untuk keperluan analisis tanah.

\section{Pengambilan Sampel dan Identifikasi Organisme Tanah}

Populasi cacing tanah diamati pada piringan pohon, gawangan antar pohon, dan daerah rumpukan tanaman kelapa sawit dengan jumlah pengamatan sebanyak 24 sampel pada masing-masing lokasi. Masing-masing pengamatan terdiri dari 3 titik sampel. Pengamatan populasi cacing tanah dilakukan menggunakan petak sampler berukuran $25 \mathrm{~cm} \times 25 \mathrm{~cm}$ $x 25 \mathrm{~cm}$. Tanah pada petak sampler tersebut digali dan dihitung jumlah cacing di dalamnya secara manual (hand sorting).

Pengambilan sampel tanah untuk pengamatan mikro-meso fauna tanah dilakukan dengan bor silinder berukuran diameter $7,5 \mathrm{~cm} \times$ panjang $15 \mathrm{~cm}$. Sampel tanah diambil pada piringan pohon, rumpukan, dan gawangan antar pohon dengan jumlah masing-masing lokasi pengamatan sebanyak 24 sampel. Fauna tanah yang berada dalam sampel tanah diekstrak dengan menggunakan Barlese Tullgren di Laboratorium Biologi Tanah Pusat Penelitian Kelapa Sawit. Selanjutnya, identifikasi fauna tanah yang ditemukan dilakukan di bawah mikroskop binokuler di Laboratorium Mikrobiologi Tanah USU Medan.

Pengamatan makro fauna tanah lainnya (khususnya di permukaan tanah) dilakukan dengan pemasangan fall trap di piringan pohon, gawangan antar pohon, dan rumpukan areal tanaman kelapa sawit masing-masing pada 24 titik pengamatan. Pada setiap titik pengamatan terdiri dari satu fall trap, dengan ukuran fall trap adalah diameter $14 \mathrm{~cm}$ dan tinggi $14 \mathrm{~cm}$. Fauna tanah yang diperoleh dihitung jumlahnya dan diidentifikasi di laboratorium.

\section{HASIL DAN PEMBAHASAN}

\section{Sifat Fisik dan Kimia Tanah Gambut}

Hasil analisis sifat fisik dan kimia tanah dari lokasi penelitian disajikan pada Tabel 1. Tingkat kematangan gambut adalah pada lapisan atas $(0-10 / 20 \mathrm{~cm})$ adalah saprik dan di lapisan bawah adalam hemik 
$(10 / 20-50 \mathrm{~cm})$. Sifat fisik dan kimia tanah gambut banyak dipengaruhi oleh kegiatan antropologis dan budidaya diatasnya. Pada lokasi penelitian, hal ini dipengaruhi tingginya kemasaman tanah $(\mathrm{pH}=3,5)$ yang disebabkan oleh akumulasi dari bahan organik yang belum mengalami dekomposisi sempurna. Bobot isi tanah gambut tergolong sangat rendah sehingga berdampak pada besarnya porositas tanah. Persentase kadar air tanah dan derajat kemasaman tanah memiliki hubungan erat dengan populasi dari biota tanah. Tanah yang cenderung masam dan berkadar air tinggi cenderung memiliki populasi biota tanah yang lebih rendah dan lebih adaptif terhadap lingkungan ekstrem. Lebih lanjut, aktivitas mikrobia juga cenderung tidak optimal akibat minimnya unsur hara pada $\mathrm{pH}$ yang rendah, kondisi muka air tanah, kadar air, berat isi dan porositas tanah gambut (Maftu'ah dan Susanti, 2009; Mishra et al., 2016; Nusantara dan Aspan, 2017; Aupic-Samain et al., 2021).

Tabel 1. Sifat fisik dan kimia tanah gambut dari kebun pengamatan

Table 1. Physical and chemistry properties of peatland at observed fields

\begin{tabular}{lc}
\hline Sifat-sifat tanah & Nilai \\
\hline $\mathrm{pH}\left(\mathrm{H}_{2} \mathrm{O}\right)$ & 3.5 \\
C-organik (\%) & 55.26 \\
Kapasitas Tukar Kation $\left(\mathrm{cmol}(+) \mathrm{kg}^{-1}\right)$ & 106.17 \\
Kemasaman Total $(\%)$ & 4.35 \\
Kadar Abu (\%) & 4.73 \\
Bobot Isi $\left(\mathrm{g} \mathrm{cm}{ }^{-3}\right)$ & 0.17 \\
Kadar Air pF2.54 $\left(\%, \mathrm{w} \mathrm{w}^{-1}\right)$ & 375,93 \\
Kadar Air pF4.2 (\%, w w $\left.{ }^{-1}\right)$ & 179.10 \\
Kematangan gambut & Saprik-Hemik \\
\hline
\end{tabular}

\section{Kerapatan makro fauna tanah}

Indikator kualitas tanah gambut dipengaruhi oleh organisme tanah yang terdiri dari makro, meso, maupun mikro fauna tanah (Briones, 2014). Semakin banyak ragam dan jumlah organisme tanah, maka hal ini menjadi indikator tingkat kesuburan tanah gambut yang semakin tinggi. Gambar 1 menunjukkan populasi dan Gambar 2 merupakan dokumentasi organisme tanah yang ditemukan pada tanah gambut di perkebunan kelapa sawit, yaitu di daerah piringan pohon, gawangan antar pohon, dan pada rumpukan. Gambar 3 menunjukkan populasi mikroorganisme tanah berupa bakteri dan jamur pada piringan pohon dan rumpukan.

Berdasarkan Gambar 1, diketahui bahwa jumlah makro dan mesofauna ditemukan paling banyak pada areal rumpukan, dan diikuti dengan piringan pohon serta gawangan antar pohon. Sebanyak $50 \%$ dari total makro dan mesofauna yang ditemukan berperan sebagai herbivora di ekosistem, lalu diikuti dengan detrivor, predator dan parasitoid dengan persentase masing-masing yaitu $27,7 \%, 16,67 \%$, dan $5,5 \%$. Tingginya jumlah makro dan mesofauna tanah pada daerah rumpukan diduga berkaitan dengan akumulasi bahan organik yang lebih banyak dari pelepah kelapa sawit, dan kelembaban tanah yang cenderung lebih tinggi pada daerah tersebut karena areal yang tertutup. Hal ini sesuai dengan hasil penelitian AshtonButt et al., (2018) dimana diversitas dan densitas fauna tanah lebih banyak ditemukan pada daerah gawangan tempat diletakkannya pelepah karena iklim mikro yang lebih terjaga dibandingkan di daerah piringan.

Selanjutnya, merujuk pada Tabel 2 diketahui bahwa kepadatan makro fauna tanah, baik di piringan pohon, gawangan maupun di rumpukan didominasi oleh jenis semut dan cacing tanah. Namun untuk cacing tanah, baik di piringan pohon, gawangan maupun di rumpukan, tidak terlalu menunjukkan peningkatan yang begitu besar atau dapat dikatakan relatif stabil. 


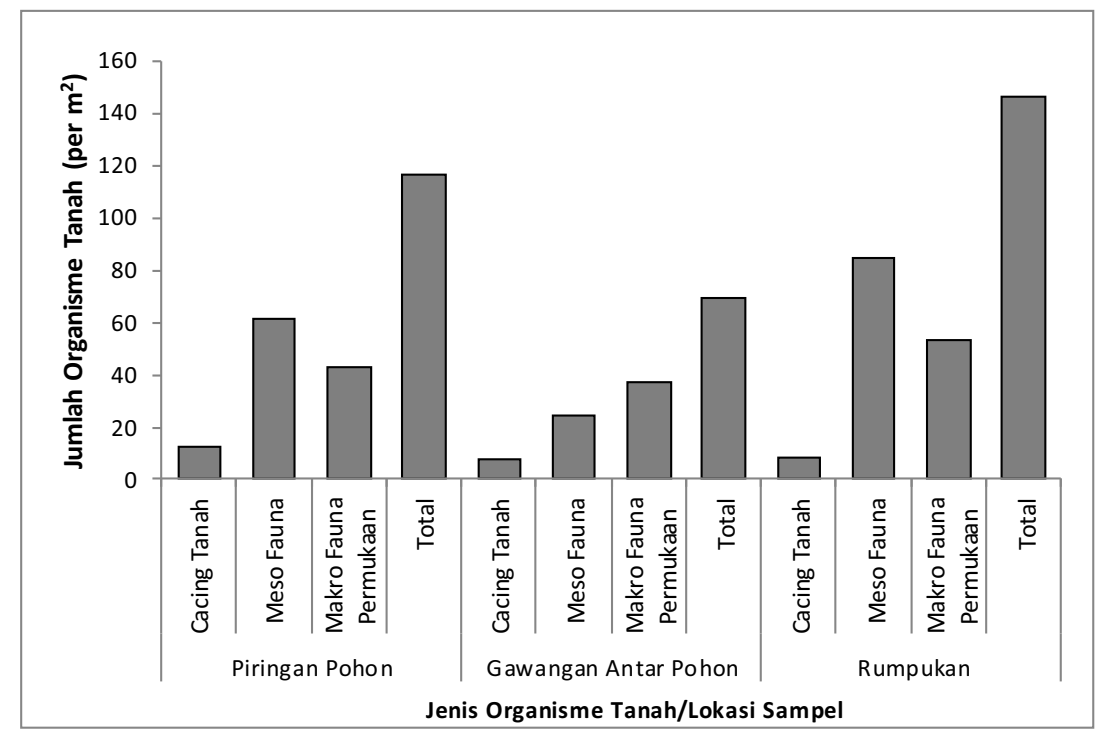

Gambar 1. Jumlah fauna tanah pada piringan pohon, gawangan antar pohon dan rumpukan

Figure 1. Total of soil fauna in weeded circle, inter-row, and between frond stacks

Peningkatan jenis Hymenoptera (semut) tersebut dapat disebabkan bahwa Hymenoptera (semut) hidup secara berkoloni dan relatif bersarang di dalam tanah. Wallwork (1970), menyatakan bahwa semut merupakan serangga sosial yang hidup secara berkoloni dan membentuk sarang atau gundukan tanah sebagai tempat berlindung. Pada perkebunan kelapa sawit semut berperan sebagai serangga herbivora dengan sumber makanan seresah tanaman, sekaligus predator atau musuh alami yang mengkonsumsi berbagai fauna di permukaan tanah, serasah dan kanopi. Semut juga membantu dalam proses penyerbukan tanaman, dan dekomposer dari bahan organik (Muhammad and Yono, 2012; Abtar dan Burhanuddin., 2013; Falahudin, 2013; Latumahina et al., 2013).

Lebih rendahnya populasi mesofauna seperti kelas Collembola (springtail) dan subkelas Acari (tungau tanah) dikarenakan tanah gambut yang cenderung masam, adaptasi setiap spesies berbeda-beda, dan tingginya curah hujan sehingga akan terbawa air hujan. Selain itu, Collembola juga berpotensi sebagai mangsa alternatif bagi predator semut (fomicidae) sehingga hal ini akan mempengaruhi kepadatannya. Menurut Lisnawati et al., (2014), Acari umumnya ditemukan pada lahan gambut yang belum mengalami dekomposisi lanjut dengan kondisi kadar air dan kelembaban tanah sedang, dijaga populasi dan diversitasnya dengan manajemen air yang baik.
Sementara, populasi dan keragaman dari Collembola sangat dipengaruhi oleh kemasaman tanah, kandungan nitrogen, perubahan iklim, serta pengelolaan lahan pertanian yang intensif (Rusek, 2004; Santamaria et al., 2012; Santonja et al., 2018; Aupic-Samain et al., 2021).

Collembola dan Acari adalah subkelas dan kelas dari fauna tanah yang padat di hutan dengan keanekaragaman jenis tumbuhan tinggi dan tebal serasahnya. Collembola juga berperan sebagai bioindikator dari penerapan manajemen pertanian yang baik, serta mempengaruhi proses dekomposisi bahan organik, dan ketersediaan hara $\mathrm{K}, \mathrm{Mg}$, dan $\mathrm{N}$ tanah (Lisnawati et al., 2014, George et al., 2017; Chauvat dan Forey, 2021). Kepadatan Collembola dan Acari akan menurun di habitat yang lebih kompleks seperti hutan, dibandingkan dengan lahan pertanian atau lahan terbuka. Hal ini disebabkan oleh beberapa faktor cekaman bagi densitas dan keragaman makro fauna tanah seperti berbedanya kadar bahan organik tanah, suhu, dan kelembaban tanah (Tsiafouli et al., 2015, Arroyo et al., 2013, George et al., 2017). Kepadatan Collembola juga memiliki keterkaitan signifikan dengan suhu tanah. Meskipun demikian, hasilnya menunjukkan variasi dan kontradiksi pada ekosistem yang berbeda-beda sesuai dengan sifat toleran jenis Collembola tertentu terhadap tekanan lingkungan. Umumnya Collembola lebih adaptif dan dapat berkembang lebih baik pada 
areal yang lebih lembab dengan suhu tanah lebih rendah, dibandingkan pada suhu tanah yang tinggi, serta cenderung berpindah ke lapisan tanah yang lebih dalam untuk mendapatkan habitat yang ideal (Heineger et al., 2014; Suhadi et al., 2020). Namun, pada penelitian ini, populasi Collembola lebih tinggi pada areal piringan pohon dengan suhu tanah yang lebih tinggi, dan kelembaban lebih rendah. Hal ini sesuai dengan penelitian Yan et al (2015) di China yang menyatakan peningkatan suhu tanah akan meningkatkan populasi Collembola karena terjadinya akselerasi dari proses perkembangan embrionya sehingga perbanyakan populasinya terjadi dalam waktu yang lebih singkat, namun keragaman spesiesnya cenderung tidak berubah. Wiles and Krogh (1998) menambahkan siklus hdup dari Folsomia candida, salah satu spesies Collembola, memerlukan waktu 240 hari pada suhu $15^{\circ} \mathrm{C}$, dan mengalami percepatan waktu siklus menjadi 110 hari pada suhu $24^{\circ} \mathrm{C}$.

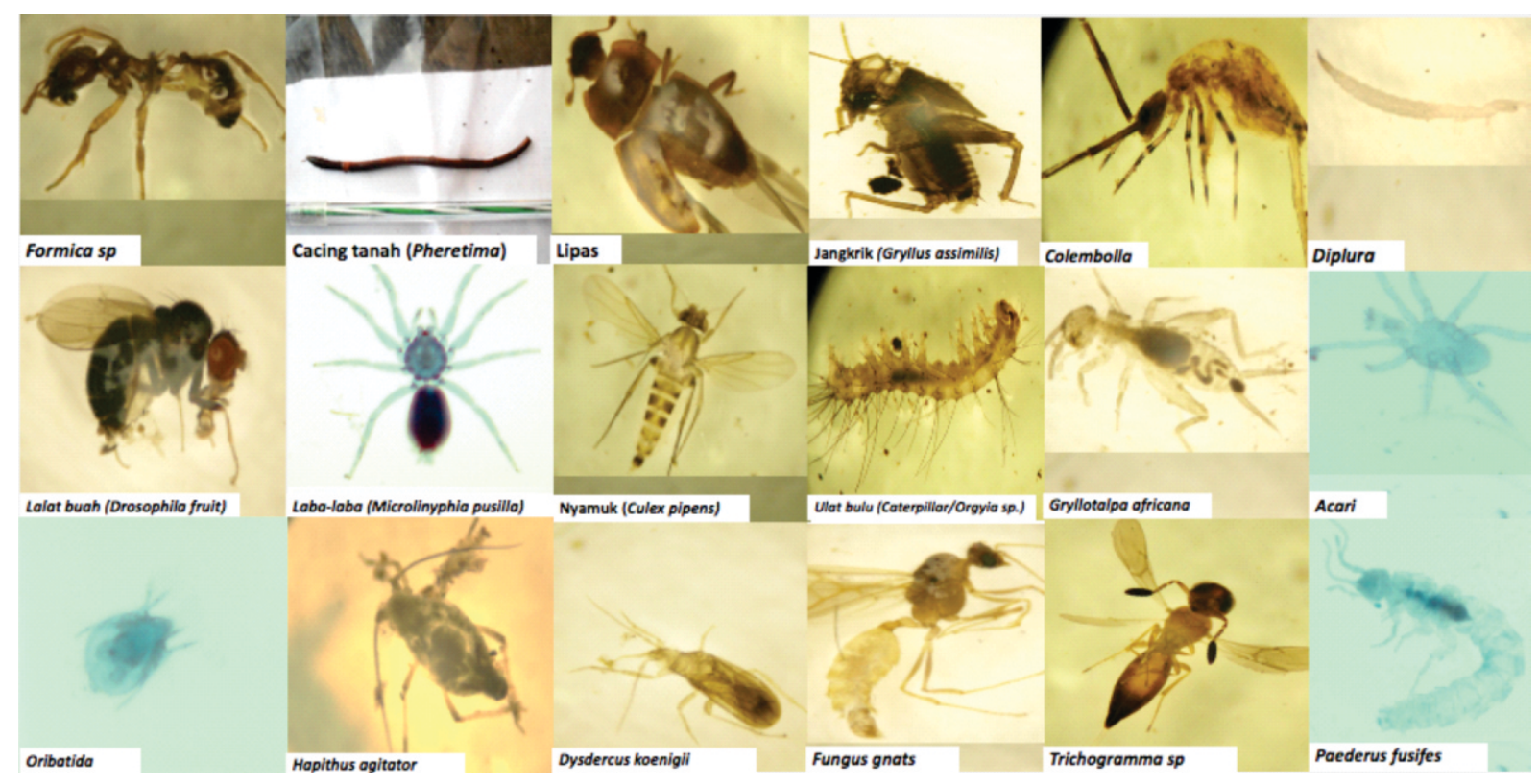

Gambar 2. Dokumentasi fauna tanah gambut pada lokasi pengamatan

Figure 2. Soil fauna in peatland at observation sites

Meso fauna tanah yang berada dalam dua kelas tersebut dapat dijadikan sebagai bio indikator kualitas tanah gambut karena sangat sensitif terhadap perubahan lingkungan (Lisnawati et al., 2014). Selain itu, Collembola turut berperan dalam meningkatkan aktivitas perombakan bahan organik, meningkatkan perpindahan $\mathrm{C}$ dari serasah ke dalam tanah (Chamberlain et al., 2006), transfer C ke komunitas mikroba (George et al., 2017) dan pembentukan mikro struktur tanah (Rusek, 2004).

\section{Populasi mikro organisme tanah}

Bakteri dan jamur tanah merupakan kelompok mikroorganisme eukariotik yang berperan penting sebagai agen mikrobiom yang mampu menjaga dan meningkatkan dekomposer tanah (Fraç et al., 2018). Selain itu, bakteri dan jamur juga berfungsi sebagai regulator ekosistem, dan dekomposer tanah melalui produksi sejumlah enzim ekstraseluler yang membantu proses degradasi bahan organik tanah, dimana selanjutnya turut berkontribusi dalam meregulasi keseimbangan karbon organik dan hara dalam tanah (Swift, 2005; Žifćkova et al., 2016).

Jumlah mikroorganisme tanah seperti kelompok bakteri dan jamur pada lokasi pengamatan diketahui paling mendominasi pada areal rumpukan dibandingkan piringan tanaman. Hal tersebut dikarenakan kelembaban yang lebih tinggi dan suhu yang lebih rendah di areal rumpukan pelepah bila 
dibandingkan dengan areal piringan yang cenderung lebih terbuka. Pernyataan ini sesuai dengan studi dari Myers et al., (2011), López-Bucio et al., (2015), Rouphael et al., (2015), Fraç et al., (2018) yang menyatakan bahwa keragaman serta aktivitas dari bakteri dan fungi dipengaruhi oleh faktor biotik (tanaman dan organisme lain) serta abiotik seperti $\mathrm{pH}$, kelembaban, temperatur dan struktur tanah. Berdasarkan penelitian Ohiwal et al., (2017) diketahui bahwa total mikroba tertinggi dan mikroba selulotik ditemukan pada gambut dangkal ( $<3$ meter) di bawah tegakan kelapa sawit umur 6 tahun, sedangkan pada tanaman berumur 15 tahun, populasi azotobacter, mikroba pelarut fosfat, dan jamur lebih banyak ditemukan pada gambut dalam ( $>3$ meter). Eksudat akar kelapa sawit diindikasikan sebagai salah satu penentu dalam populasi mikroba, terutama pada daerah rhizosfer tanaman karena berperan sebagai sumber energi mikroba dalam beraktivitas selain sumber bahan organik dari biomassa tanaman.

Tabel 2. Kerapatan organisme tanah yang ditemukan pada tanah gambut di perkebunan kelapa sawit Table 2. Soil organisms density that discovered in oil palm on peat

\begin{tabular}{lcccc}
\hline \multicolumn{1}{c}{ Organisme Tanah } & $\begin{array}{c}\text { Piringan } \\
\text { Pohon } \\
\text { (individu } \mathrm{m}^{-2} \text { ) }\end{array}$ & $\begin{array}{c}\text { Gawangan } \\
\text { Antar Pohon } \\
\text { (individu } \mathrm{m}^{-2} \text { ) }\end{array}$ & $\begin{array}{c}\text { Rumpukan } \\
\text { (individu } \mathrm{m}^{-2} \text { ) }\end{array}$ & Fungsi \\
\hline Semut (Formica) & 31.09 & 18.36 & 42.33 & Predator \\
Cacing (Lumbricus) & 12.44 & 6.44 & 8.00 & Detrivore \\
Lipas & 8.24 & 10.49 & 10.11 & Detrivore \\
Jangkrik (Gryllus assimilis) & 4.12 & 3.37 & 1.87 & Herbivore \\
Collembola & 4.12 & 1.87 & 2.25 & Detrivore \\
Diplura & 3.00 & 0.00 & 3.75 & Detrivore \\
Lalat Buah (Drosophila fruit) & 1.87 & 3.00 & 5.62 & Herbivore \\
Laba-laba (Spider) & 1.50 & 3.00 & 4.12 & Predator \\
Nyamuk (Culex pipens) & 1.12 & 0.00 & 2.62 & Herbivore \\
Ulat bulu (Caterpillar/ Orygia sp.) & 1.12 & 2.25 & 3.75 & Herbivore \\
Anjing tanah & & & & \\
(Gryllotalpa africana) & 1.50 & 0.37 & 0.37 & Herbivore \\
Acari & 1.12 & 0.37 & 0.00 & Herbivore \\
Oribatida & 0.75 & 0.37 & 0.00 & Detrivore \\
Hapithus agitator & 0.00 & 0.37 & 0.00 & Herbivore \\
Dysdercus koenigii & 0.37 & 0.00 & 0.00 & Herbivore \\
Fungus gnats & 0.37 & 0.00 & 0.37 & Herbivore \\
Trichogramma sp & 0.00 & 0.37 & 0.37 & Parasitoid \\
Paederus littoralis & 0.00 & 0.00 & 0.37 & Predator \\
\hline Jumlah & 72.75 & 50.65 & 85.92 & \\
\hline
\end{tabular}

Selanjutnya, sesuai dengan hasil penelitian Ali et al., (2018) pada ekosistem gambut dengan tegakan kelapa sawit, populasi organisme eukariotik akan meningkat seiring dengan tingginya curah hujan, kelembaban tanah, dan bertambahnya masukan biomassa organik terutama pada areal rumpukan 
dalam studi ini. Aktifitas antropogenik seperti pembuatan saluran drainase, pengurangan tingkat kejenuhan air, serta budidaya kelapa sawit pada lahan gambut berdampak pada meningkatnya diversitas organisme eukariotik disebabkan oleh oksigen dan bahan organik dari biomassa yang lebih tersedia, sehingga aktivitas organisme eukariotik berjalan lebih intensif.

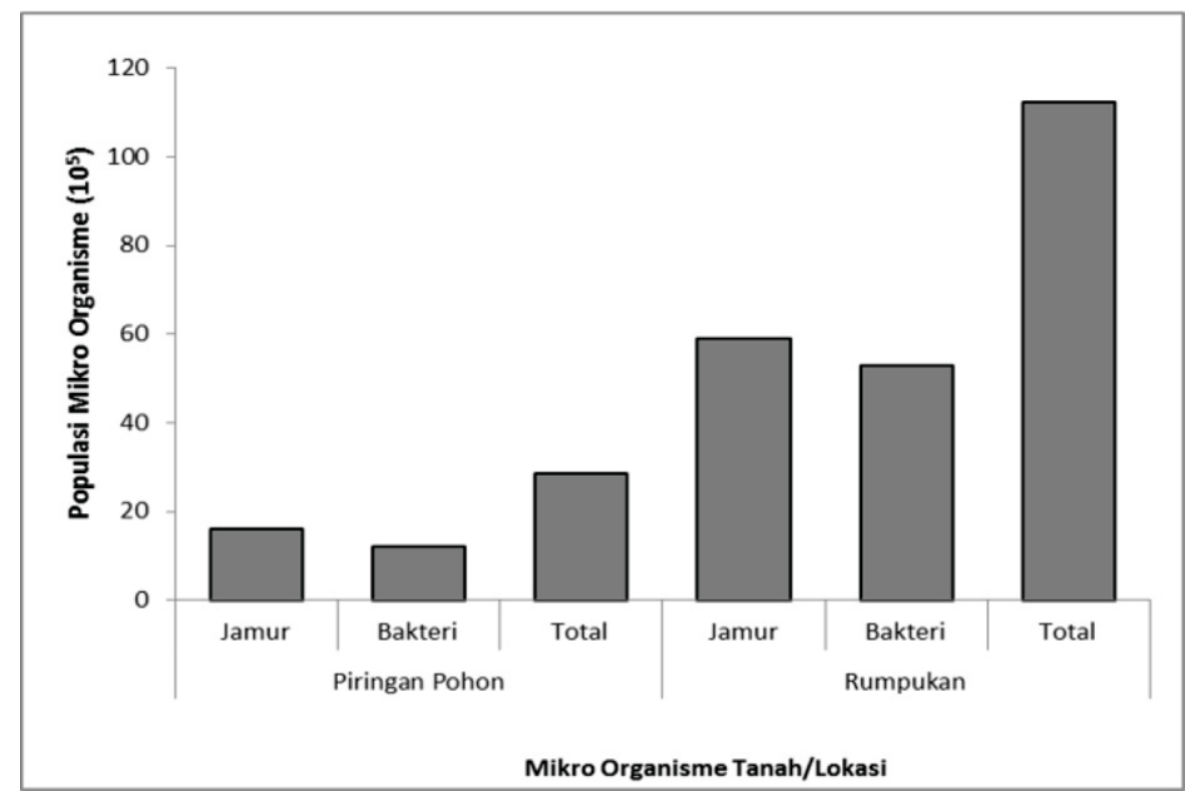

Gambar 3. Populasi bakteri dan jamur di piringan pohon dan rumpukan tanaman kelapa sawit Figure 3. Bacteria and fungi population in weeded circle and frond stacks of oil palm

\section{Hubungan Organisme Tanah Terhadap Sifat Tanah Gambut}

Tabel 3 menunjukkan koefisien korelasi hubungan antara jumlah fauna tanah dengan sifat-sifat tanah gambut di lokasi penelitian. Jumlah fauna tanah berkorelasi positif terhadap suhu, hal ini menunjukkan semakin tinggi suhu baik di dalam piringan pohon maupun di luar piringan pohon maka jumlah fauna tanah dan mikroorganisme tanah akan meningkat. Semua proses pertumbuhan organisme bergantung pada reaksi kimiawi, dimana laju reaksi-reaksi ini dipengaruhi oleh suhu (Myers et al., 2011. Jumlah fauna tanah dan mikroorganisme tanah juga menunjukkan hubungan positif terhadap $\mathrm{pH}$ tanah. Hal ini mengindikasikan bahwa peningkatan $\mathrm{pH}$ tanah akan meningkatkan jumlah fauna dan mikroorganisme pada lokasi studi. Begum et al (2014) juga menyatakan hal serupa, dimana $\mathrm{pH}$ atau derajat kemasaman tanah berkorelasi positif dan signifikan terhadap kelimpahan makrofauna seperti dari jenis Aranea, Potworm, Aphidae, Acari, Chilopoda, Hemiptera, Hymenoptera,

\section{dan Orthoptera.}

Kadar air tanah menunjukkan korelasi positif dengan jumlah organisme tanah, dimana peningkatan kadar air tanah akan meningkatkan populasinya. Hal ini didukung oleh pernyataan Hani dan Suhaendah (2019), bahwa kadar air tanah berpengaruh secara langsung terhadap kehidupan serangga tanah, dengan kelembaban yang tinggi serangga masih dapat bertahan. Namun, kadar air tanah yang berlebihan dan bertahan lama akan membatasi aktivitas dan bergerak, maka serangga tanah bisa mengalami kematian atau bermigrasi. Minnich (1997) menyebutkan bahwa pada kelembaban yang terlalu tinggi atau terlalu banyak air, cacing tanah cenderung lebih sedikit dan berpindah ke bagian tanah dengan tempat pertukaran udara (aerasi) lebih baik. Lebih lanjut, Ma et al (2020) menyatakan bahwa cacing tanah juga berperan dalam memperbaiki kapasitas tanah memegang air, dan mengurangi evaporasi air tanah. Wu et al., (2017) turut menambahkan bahwa pada ekosistem gambut, aktivitas cacing tanah 
cenderung lebih aktif pada tingkat kelembaban tanah yang rendah yaitu pada saat gambut tidak jenuh air dan muka air tanah menurun. Hal ini juga akan secara sinergis meningkatkan pelepasan karbon organik tanah pada gambut.

Hal ini terjadi karena cacing tanah mengambil oksigen dari udara bebas untuk pernafasannya melalui kulit. Fauna tanah gambut banyak ditemukan pada lapisan atas tanah gambut di lokasi penelitian karena kelembaban tanah pada kondisi kapasitas lapangan yaitu berkisar $250-350 \%(\mathrm{w} / \mathrm{w})$ atau setara dengan 50 $-70 \%$ (v/v). Semakin ke lapisan dalam tanah gambut, maka semakin sedikit fauna tanah ditemukan karena kadar air tanah yang semakin tinggi.

Jumlah fauna dalam piringan pohon dan di luar piringan pohon berkorelasi negatif dengan $\mathrm{C} / \mathrm{N}$ tanah gambut, hal ini disebabkan aktivitas mesofauna tanah berfungsi untuk menguraikan sisa-sisa bahan organik dan menggunakan $\mathrm{C}$ sebagai sumber energi dan mempengaruhi fluks hara dalam tanah (Tan et al., 2020; Frouz, 2018; Dervash et al., 2018). Salehi et al (2013) menyebutkan bahwa aktivitas cacing tanah meningkatkan ketersediaan hara tanah, meningkatkan laju siklus hara, menurunkan $\mathrm{C} / \mathrm{N}$ tanah.

Tabel 3. Koefisien korelasi hubungan kepadatan organisme tanah dengan parameter sifat-sifat tanah gambut Table 3. Correlation coefficient of soil organisms density with peatland properties parameters

\begin{tabular}{lcc}
\hline Sifat-sifat Tanah & $\begin{array}{c}\text { Organisme Tanah } \\
\text { Dalam Piringan Pohon }\end{array}$ & $\begin{array}{c}\text { Organisme Tanah } \\
\text { Luar Piringan Pohon }\end{array}$ \\
\hline Suhu & 0.66 & 0.58 \\
$\mathrm{pH}$ & 0.26 & 0.31 \\
$\mathrm{KA}$ & 0.17 & 0.12 \\
$\mathrm{C} / \mathrm{N}$ & -0.59 & -0.4 \\
Respirasi Tanah & 0.54 & 0.10 \\
\hline
\end{tabular}

Berdasarkan korelasi pada Tabel 3diketahui bahwa jumlah fauna tanah berhubungan positif dengan respirasi tanah, hal ini menunjukkan bahwa peningkatan jumlah organisme tanah akan meningkatkan respirasi tanah. Hal ini sesuai dengan hasil riset Batubara et al., (2019) dimana bakteri memiliki peran penting dalam respirasi tanah dibandingkan mikroba lainnya. Lebih lanjut, respirasi tanah akan berkurang seiring dengan bertambahnya kedalaman gambut, namun akan bertambah dengan semakin meningkatnya kematangan gambut (Saprik > Hemik).

Dalam beberapa studi sebelumnya, rasio aktivitas fungi:bakteri yang lebih besar akan menunjukkan total biomassa mikroba yang lebih besar namun respirasinya kurang begitu tinggi dan tidak menunjukkan keterkaitan yang jelas terhadap laju produksi $\mathrm{CO}_{2}$ dan pelepasan karbon (C) dari gambut (Myers et al., 2011). Hal ini diindikasikan terjadi sebab tingkat dekomposisi, kematangan, dan kadar air gambut yang beragam. Hardjowigeno (1987) menyatakan bahwa organisme yang bermanfaat antara lain cacing tanah dan bakteri tertentu yang dapat mengubah $\mathrm{CO}$ (karbon monoksida) yang beracun menjadi $\mathrm{CO}_{2}$ (karbon dioksida) atau mengikat $\mathrm{N}$ dari udara. Proses dekomposisi merupakan lepasnya ikatan-ikatan karbon yang komplek menjadi ikatan-ikatan sederhana akibat penggunaan unsur $\mathrm{C}$ oleh organisme untuk mendapatkan energi keperluan hidupnya melalui proses respirasi dan biosintesis melepaskan $\mathrm{CO}_{2}$, sehingga bahan organik yang telah mengalami proses dekomposisi akan mempunyai kadar $\mathrm{C}$ lebih rendah dibanding dengan kadar $\mathrm{C}$ bahan segar. Hal ini sesuai dengan Cabral (2012) dimana nilai $\mathrm{C} / \mathrm{N}$ menunjukkan tingkat dekomposisi materi organik, dimana semakin kecil nilainya maka semakin lanjut tingkat dekomposisi yang sedang berlangsung.

\section{KESIMPULAN}

Organisme tanah (makro, mesofauna dan mikroorganisme) spesifik kondisi lingkungan dapat berperan sebagai bio indikator kualitas tanah gambut dan tingkat pengelolaan lahan. Aktivitas antropologi 
seperti budidaya kelapa sawit memberikan pengaruh terhadap populasi dan diversitas dari organisme tanah. Meskipun tanah gambut dikenal memiliki kesuburan rendah dengan tingkat kemasaman yang tinggi, namun pada penelitian ini ditemukan populasi dan diversitas fauna serta organisme tanah yang relatif beragam dengan fauna tanah paling banyak adalah semut dan cacing tanah. Baik makro, mesofauna, dan mikroorganisme eukariotik (bakteri dan jamur) ditemukan mendominasi pada areal rumpukan dibandingkan areal piringan karena kondisi iklim mikro yang lebih mendukung.

\section{DAFTAR PUSTAKA}

Abtar, H., dan Burhanuddin, N. 2013. Komunitas semut (Hymenoptera:Formicidae) pada tanaman padi, jagung, dan bawang merah. Jurnal Agroteknologi dan Bisnis. 1(2): 109112.

Ali, S.R.A., Mat Isa, M.N., Safari, S., Maidin, M.S.T., and Ibrahim, S.A.S. 2018. Eukaryotic biodiversity in mixed peat ecosystems in Sarawak, Malaysia. Journal of Oil Palm Research. 30: 429-450. https://doi.org/10.21894/jopr.2018.0023.

Arifin, Atmojo, S.W., Setyono, P. and Dewi, W.S. 2015. Temperature effect investigation toward peat surface $\mathrm{CO} 2$ emission by planting leguminous cover crops in oil palm plantations in west Kalimantan. Journal of agricultural science and technology. 5: 170183. doi: 10.17265/2161-6264/2015.03.002

Arroyo, J., Keith, A.M., Schmidt, O., Bolger, T., 2013. Mite abundance and richness in an Irish survey of soil biodiversity with comments on some newly recorded

species. Irish Naturalists' Journal. 33: 19-27.

Ashton-Butt, A., Aryawan, A.A.K., Hood, A.S.C., Naim, M., Purnomo, D., Suhardi, Wahyuningsih, R., Willcock, S., Poppy, G.M., Calliman, J., Turner, E.C., Foster, W.A., Peh, K.S.H., and Snaddon, J.L. 2018. Understory vegetation in oil palm plantation benefits soil biodiversity and decomposition rates. Front. For. Glob. Change. 1(10): 1-13. doi: 10.3389/ffgc.2018.00010

Aupic-Samain, A., Santonja, M., Chomel, M., Pereira, S., Quer, E., Lecareux, C., Limousin, J., Ourcival, J., Simioni, G., Gauquelin, T., Fernandez, C., and Baldy, V. 2021. Soil biota response to experimental rainfall reduction depends on the dominant tree species in mature northern Mediterranean forests. Soil biology and biochemistry. 154

Barnes, B.V., Donald R.Z., Shirley R.D. and Stephen H.S. 1997. Forest Ecology.4th Edition. John Wiley and Sons Inc., New York.

Batubara, S.F., Agus, F., Rauf, A., and Elfiati, D. 2019. Soil respiration and microbial population in tropical peat under oil palm plantation. IOP Conf. Series: Earth and Environmental Science. 260: 1-9. doi:10.1088/1755-1315/260/1/012083

Begum, F., Zuhra, B., Khan, A., Durrani, S.A., Ali, S., Ali, K., and Ishaq, S. 2014. Study of soil macrofauna in relation with some of selected soil physio-chemical properties at sumayarnagar in district hunza-Nagar GilgitBaltistan, Pakistan. Journal of Biodiversity and Environmental Sciences. 5(3):124-132.

Bhadauria, T., and Saxena, K.G. 2010. Role of earthworms in soil fertility maintenance through the production of biogenic structures. Applied and Environmental Soil Science, 816073. 1-7.

Briones. 2014. Soil Fauna And Soil Functions: A Jigsaw Puzzle. Front. Environ. Sci. doi: https://Doi.Org/10.3389/Fenvs.2014.00007

Cabral, M.R. 2012. Relation and Change Over Time of CN-Ratios Throughout Swedish Peatlands and in Seven Fertility Classes [Thesis]. Swedish University of Agricultural Sciences. Swedia.

Chamberlain, P.M., Mc Namara, N.P., Chaplow, J., Stott, A.W., dan Black, H.I.J. 2006. 
Translocation of Surface Litter Carbon into Soil by Collembola. J. Soil Biology and Biochemistry (38) : 2655 -2664.

Chauvat, M., and Forey, E. 2021. Temperature modifies the magnitude of a plant response to Collembola presence. Applied Soil Ecology. 158: 103814 . Doi : 10.1016/j.apsoil.2020.103814

Dervash, M.A., Bhat, R.A., Mushtaq, N., and Singh, D.V. 2018. Dynamics and importance of soil mesofauna. International Journal of Advance Research in Science and Engineering. 7(4): 2010-2019.

Falahudin I. 2013. Peranan semut rangrang (Oecophylla smaragdina) dalam pengendalian biologis pada perkebunan kelapa sawit. Konferensi AICIS XII. IAIN Raden Fatah. 2604-2618. Diakses melalui http://digilib.uinsby.ac.id.

Fraç, M., Hannula, S.E., Be ka, M., and Je dryczka, M. 2018. Fungal Biodiversity and Their Role in Soil Health. Front. Microbiol. 9:707. doi: 10.3389/fmicb.2018.00707

Frouz, J. 2018. Effects of soil macro- and mesofauna on litter decomposition and soil organic matter stabilization. Geoderma. 332: $\begin{array}{lllllll}1 & 6 & 1 & - & 1 & 7 & 2\end{array}$. doi:10.1016/j.geoderma.2017.08.039

George, P.L., Keith, A.M., Simon, C., Gaynor, L.B., Inma, L., Bridget, A.E., David, A.R., and David, L.J. 2017. Evaluation of mesofauna communities as soil quality indicators in a national-level monitoring programme. Soil biology and biochemistry. 115:537-546. https://doi.org/10.1016/j.soilbio.2017.09.02 2.

Hani, A., and Suhaendah, E. 2019. Diversity of soil macro fauna and its role on soil fertility in manglid agroforestry. Indonesian Journal of Forestry Research. 6(1): 61-68.

Hardjowigeno, S. 1987. Sumber Daya Fisik Wilayah dan Tata Guna Lahan: Histosol. Fakultas Pertanian Institut Pertanian Bogor.
Heineger, C., Barot, S., Ponge, J-F., Salmon, S., Botton-Divet, L., Carmignac, D. and Dubs, F. 2014. Effect of habitat spatiotemporal structure on Collembolan diversity. Pedobiologia - Journal of Soil Ecology. $\begin{array}{llllllllll}5 & 7 & : & 1 & 0 & 3 & - & 1 & 1 & 7\end{array}$. http://dx.doi.org/10.1016/j.pedobi.2014.01.0 06

Latumahina, F.S., Musyafa, Sumardi, dan Putra, N.S. 2013. Keragaman semut pada penggunaan lahan permukiman dalam hutan lindung Sirimau Kota Ambon. Biota. 18(2): 67-74.

Lisnawati, Y., Suprijo, H., Poedjirahajoe, E., dan Mustafa. 2014. Hubungan kedekatan ekologis antara fauna tanah dengan karakteristik tanah gambut yang di drainase untuk HTI Acacia crassicarpa. J. Manusia dan Lingkungan. 21(2): 170-178.

López-Bucio, J., Pelagio-Flores, R., and HerreraEstrell, A. 2015. Trichoderma as biostimulant: exploiting the multilevel properties of a plant beneficial fungus. Sci. Hortic. $196,109-123$. doi : 10.1016/j.scienta.2015.08.043

Maftu'ah, Alwi, M., dan Willis, M. 2005. Potensi makrofauna tanah sebagai bioindikator kualitas tanah gambut. Bioscientiae. 2(1):114.

Maftu'ah, E. dan M.A. Susanti. 2009. Komunitas cacing tanah pada beberapa penggunaan lahan gambut di Kalimantan Tengah. Berita Biologi. 9(4): 371-378.

Ma, L., Shao, M., and Li, T. 2020. Characteristics of soil moisture and evaporation under the activities of earthworms in typical Anthrosols in China. Sustainability. 12: 6603. doi:10.3390/su12166603.

Minnich, Y. 1997. The Earthworm Book. Press Emnous. Rodale Britania.

Mishra, S., Yi, Y.P., Shivshankar, U., Moses, D., Idris, A., Schuster, S., and Swarup, S. 2016. Developing sustainable practices to mitigate 
impacts of climate change on natural and managed tropical peatland. In 15 th International peat Congress 2016, Kuching, Sarawak, Malaysia.

Muhammad, A. and Kono, Y. 2012. The role of ants and termites in peat decomposition process. Proceeding of The Association for Tropical Biology \& Biodiversity Conservation's AsiaPacific Chapter Annual Meeting. 24-27 March 2012. Xishuangbanna. Page 63.

Myers, B., Webster, K.L., Mclaughlin, J.W., and Basiliko, N. 2011. Microbial activity across a boreal peatland nutrient gradient: the role of fungi and bacteria. Wetlands Ecology and $\mathrm{M}$ a $\mathrm{n}$ a $\mathrm{g}$ e $\mathrm{m}$ e $\mathrm{nt}, \quad 20$ ( 2 ), 77-88.doi:10.1007/s11273-011-9242-2

Nusantara, R.W., and Aspan, A. 2017. Differentiation of soil organisms at different types of peatland in West Kalimantan, Indonesia. Bonorowo Wetlands. 7(1) : 2630.

Ohiwal, M., Widyastuti, R., Sabiham, S. 2017. Populasi mikrob fungsional pada rhizosfer kelapa sawit di lahan gambut riau. J. II. Tan. Lingk. 19(2):74-80.

Rusek, J. 2004. Biodiversity of Collembola and their functional role in the ecosystem. Biodiversity and Conservation. 7(9), 12071219.

Salehi, A., Ghorbanzadeh, N., and Kahneh, E. 2013. Earthworm biomass and abundance, soil chemical and physical properties under different poplar plantations in the north of Iran. Journal of forest science. 59 (6): 223 229.

Santamaria, J.M., Moraza, M.L., Elustundo, D., Baquero, E., Jordana, R., Lasheras, E., Bermejo, R., and Ariño, A.H. 2012. Diversity of Acari and Collembola along a pollution gradient in soils of a pre-pyrenean forest ecosystem. Environmental engineering and management journal. 11(6):1159-1169.
Santonja, M., Aupic-Samain, A., Forey, E., and Chauvat, M. 2018. Increasing temperature and decreasing specific leaf area amplify centipede predation impact on Collembola. European Journal of Soil Biology. 89: 9-13. doi:10.1016/j.ejsobi.2018.08.002

Suhadi, Dharmawan, A., Nafiah, K., Akhasani, F., and Yulianita, A. 2020. Comparative study of Collembola community on post fire land, transitional land, and control land in Teak forest Baluran National Park Situbondo. AIP Conference Proceedings. 2231, 040058. doi: https://doi.org/10.1063/5.0002694

Swift, M.J. 2005. Human impacts on biodiversity and ecosystem services: an overview, in The Fungal Community its Organization and Role in Ecosystems, eds J. Dighton, J. F. White, and P. Oudemans (Boca Raton, FL: CRC Press). 627-641.

Tan, B., Yin, R., Zhang, J., Xu, Z., Liu, Y., He, S., Zhang, L., Li, H., Wang, L., Liu, S., You, C., and Peng, C. 2020. Temperature and moisture modulate the contribution of soil fauna to litter decomposition via different pathways. Ecosystems . 1-15. https://doi.org/10.1007/s10021-020-00573w

Tsiafouli, M.A., Thébault, E., Sgardelis, S.P., de Ruiter, P.C., van der Putten, W.H.,

Birkhofer, K., Hemerik, L., de Vries, F.T., Bardgett, R.D., Brady, M.V., Bjornlund, L., Jørgensen, H.B., Christensen, S., d'Hertefeldt, T., Hotes, S., Hol, W.H.G., Frouz, J.,Liiri, M., Mortimer, S.R., Setälä, H., Tzanopoulos, J., Uteseny, K., PiŽl, V., Stray, J., Wolters, V., Hedlund, K., 2015. Intensive agriculture reduces soil biodiversity across Europe. Global Change Biology. 21: 973-985.

Wallwork, J.A. 1970. Ecology of Soil Animal. Mc.Graw Hill Book Company. London. pp. 58-74.

Wiles, J.A., and Krogh, P.A. 1998. Tests with the Collembolans Isotoma viridis, Folsomia 
candida and Folsomia fimetaria. In Handbook of Soil Invertebrate Toxicity Tests; Løkke, H., Van Gestel, C.A.M., Eds.; John Wiley: Chichester, UK.

Winarna, Pradiko, I., Syarovy, M., dan Hidayat, F. 2016. Perbaikan sifat-sifat dan pencegahan hidrofobisitas tanah gambut di perkebunan kelapa sawit melalui aplikasi terak baja. J. Pen. Kelapa Sawit. 24(1): 39-46.

Winarna, Yusuf, M.A., Rahutomo, S., dan Sutarta, E. 2017. Dampak muka air tanah dan ameliorant terhadap kelembapan tanah, emisi CO2, dan produksi kelapa sawit pada tanah gambut. J.Pen. Kelapa Sawit. 25(3):147-160.
Wu, X., Cao, R., Wei, X., Shi, P., Elsenhauer, N., and Sun, S. 2017. Soil drainage facilitates earthworm invasion and subsequent carbon loss from peatland soil. Journal of Applied Ecology. 54:1291-1300. doi:10.1111/13652664.12894.

Yan, X.Ni, Z., Chang, L., Wang, K., and Wu, D. 2015. Soil warming elevates the abundance of Collembola in the Songnen Plain of China. Sustainability. 7: 1161-1171. doi:10.3390/su7021161

Žifcáková, L., Vetrovský, T., Howe, A., and Baldrian, P. 2016. Microbial activity in forest soil reflects the changes in ecosystem properties between summer and winter. Environ. Microbiol. 18: 288-301. doi: 10.1111/1462-2920.13026 